\title{
Kinetics of CD4+ T-cell recovery amongst HIV load suppressed patients on first-line antiretroviral therapy in Yaoundé, Cameroon
}

\author{
Cedric Happi MBAKAM ${ }^{1 *}$, Julius Mbekem NWOBEGAHAY², Cybelle FODIEU \\ MEZAJOU $^{2}$, Franklin Agueguia AZEBAZE ${ }^{1}$, Leopold Mbous NGUIMBUS ${ }^{1}$, Audrey \\ Pamela Ngouambe NGALEU ${ }^{3}$, Cédric Romuald Yapfa DJOMAHA ${ }^{3}$, Mureille MAFFO ${ }^{3}$, \\ Graeme Brendon JACOBS ${ }^{4}$, Marie Claire Okomo ASSOUMOU ${ }^{1}$, Claude Tayou TAGNY ${ }^{5}$ \\ and George Mondinde IKOMEY ${ }^{1}$
${ }^{1}$ Center for the Studies and Control of Communicable Diseases (CSCCD), Faculty of Medicine and Biomedical Sciences (FMBS), University of Yaoundé 1, Cameroon.
${ }^{2}$ Millitary Health Research Center, Yaoundé, Cameroon.
${ }^{3}$ University Institute and Strategic Estuary of Douala, Cameroon.
${ }^{4}$ Division of Medical Virology, Faculty of Medicine and Health Sciences, Stellenbosch University, Tygerberg, South Africa.
${ }^{5}$ University Teaching Hospital of Yaoundé, University of Yaoundé 1, Cameroon. \\ *Corresponding author; E-mail: cedric.happimbakam@gmail.com ; PO.BOX 8445 Melen, Yaoundé.
}

\begin{tabular}{ccc}
\hline Received: 30-01-2021 & Accepted: 22-06-2021 & Published: 30-06-2021 \\
\hline
\end{tabular}

\begin{abstract}
HIV infected patients on Antiretroviral Therapy (ART) are exposed to various immunological disorders. Immune reconstitution is one of the most challenging problem linked to morbidity and mortality in HIV patients. This study aimed at evaluating the kinetics of CD4+ T-cell recovery amongst HIV load suppressed patients on first-line ART in Yaoundé, Cameroon. This was a retrospective cohort study performed at the care and treatment units of the Yaoundé University Teaching Hospital and Essos Hospital Center, with viral suppressed patients initiated on ART between March and July 2015. Data were collected using a standard form and analyzed using R.3.6.2 software. A p $<0.05$ was considered statistically significant for a 95\%CI. Of the 499 viral suppressed participants, $32 \%(\mathrm{n}=160)$ were male and $68 \%(\mathrm{n}=339)$ female; $33 \%$ and $40 \%$ had severe and moderate immunodepression at baseline, respectively; $9 \%$ and $28 \%$ remain respectively on the same immunological state. CD4+ T-cell count increased by $73 \%, 49 \%$ and $29 \%$ for patients that started treatment, with $\mathrm{CD} 4+<150$ cells $/ \mathrm{ml}, 150<\mathrm{CD} 4+<350$ cells $/ \mathrm{ml}$ and $350<\mathrm{CD} 4+<500$ cells $/ \mathrm{ml}$, respectively and $14 \%, 34 \%$ and $40 \%$ reached a target of 500 cells $/ \mathrm{ml}$ or more after 4 years of treatment. Elder patients and males were likely to have CD4+ T-cells less than 350 Cells $/ \mathrm{ml}$. Approximately $35 \%$ of patient started treatment with CD4+ T-cells $<350$ Cells/ml. CD4+ T-cells increased significantly during 4 years of treatment but, just $29 \%$ in average achieved CD4+ $\geq 500$ cells/ml. CD4 T-cells recovery represent and important challenge in the immunological monitoring of long-term HIV infected patients on ART.
\end{abstract}

(C) 2021 International Formulae Group. All rights reserved.

Keywords: Kinetic, CD4+ T-cells, HIV, Suppressed HIV load, ART 


\section{INTRODUCTION}

HIV infection is linked to high mortality rates worldwide (Wang et al., 2016; Danforth et al. 2017) and especially in sub-Saharan Africa (Dwyer-Lindgren et al., 2019). Antiretroviral therapy (ART) leads to the maintenance of low or undetectable viral load, reduction of HIV transmission and the improvement and reconstitution of the immune system (Warren et al., 2019). The initiation on ART, followed by the significant declines of viral load leads to CD4+ redistribution and results in thymic activation (Rb-Silva et al., 2019). It has been shown that 15 to 30 percent of HIV infected individuals have suboptimal increase of CD4+ T-cells count, most commonly due to lack of compliance to ART. Some patients, because of the CD4+ T-cells recovery failure, will be at higher risk for adverse health outcomes (Darraj et al., 2018; Tough and McLaren, 2019). During the infection process, the virus replicates and induces a qualitative and quantitative CD4+ Tcells defects through several mechanisms (Okoye and Picker, 2013; Vidya Vijayan et al., 2017; Bonnet et al., 2019). The immune system responds by inducing the proliferation of $\mathrm{T}$ cells subsets, with the aim to maintain their repertoire relatively constant during the infection stage (Porichis and Kaufmann, 2011; Okoye and Picker, 2013; Darraj et al., 2018; Bonnet et al., 2019). When at a certain point, the immune system cannot maintain the high rate of $\mathrm{T}$-cell production sufficient to compensate the HIV-induced T-cells depletion, patients will develop AIDS related morbidity and mortality (Hsu et al., 2013; Pastor et al., 2018; Agosto and Henderson, 2018). Before the test and treat strategy implementation, CD4+ T-cell counts were used as the main indicator to consider the initiation of HIV infected patients on ART (Cameroon_National-Integrated-HIV-

Guidelines, 2014). Now, in some resources limited settings (RLS), the follow-up of patients on ART is based on viral progression, despite the persistence of immune system activation related to non-AIDS diseases and mortality. The study aimed at evaluating the kinetic of CD4+ T-cell recovery amongst viral suppressed patients on first-line ART for four years (from 2015 to 2019) in Yaoundé, Cameroon.

\section{MATERIALS AND METHODS Study design}

This was a retrospective cohort study performed at the care and treatment units of the Yaoundé University Teaching Hospital and Essos Hospital Center. The study population consisted of HIV infected patients on first-line ART. The enrolled participants were a cohort of patients initiated on ART between March and July 2015. The study was completed in July 2019.

All the HIV infected individuals on first-line ART were initially included. All the patients with unsuppressed viral load at baseline, those with suppressed viral load that become unsuppressed along the study period and those with non-consecutive documented HIV load and CD4+ T-cells for the period of the study, were excluded.

The first-line ART regimen according to the country guidelines were considered as follow: combination of two nucleoside reverse transcriptase inhibitors (NRTIs), chosen among Zidovudine (AZT), Tenofovir (TDF) and Lamivudine (3TC) and a non-nucleoside reverse transcriptase inhibitor (NNRTI) being either Efavirenz (EFV) or Nevirapine (NVP). The suppressed HIV load patients were defined following the WHO classification as all the patients with HIV load less than 1000 copies per milliliter of blood (WHO, 2016).

Socio-demographics and clinical characteristics were collected at the same time with biological information of the patients retained in the cohort by using a standard form. The collected information included gender, age, treatment protocol, initiation date, CD4+ count and HIV load results. Administrative authorization from Hospitals' directors were obtained. Ethical clearance was obtained from 
the Cameroon National Ethical committee (reference number 044/CNE/SE/2017) to carry out the study.

HIV load documented were obtained using the Cobas Ampli prep / Cobas Taqman 96 platform (Roche Diagnostics, Branchburg, New Jersey, USA), per manufacturer's instructions. The detection limit was $<40$ copies/ml. For CD4+ T-cells, the measurement was done based on the principle of immunophenotyping using the Pima reagent kit, and automated machine. Samples, including quality controls, were analyzed based on the manufacturers' guidelines.

\section{Statistical analyzes}

Data were analyzed using the $\mathrm{R}$ 3.6.2 software package (CRAN, R Core Team). Comparisons of $\mathrm{CD} 4+$ Tcells based on immune state and ART regimen were performed using the parametric student T-test by evaluating their means and interquartile range. The association between CD4+ Tcells and other variables were established using a logistic regression. The $\mathrm{p}<0.05$ was considered statistically significant for a $95 \%$ CI.

\section{RESULTS}

\section{Sociodemographic and clinical characteristics}

A cohort of 499 viral suppressed participants was enrolled during the period of the study. $32 \%(\mathrm{n}=160)$ were male and $68 \%$ $(\mathrm{n}=339)$ were female. At initiation on ART, $33 \%$ and $40 \%$ of those patients had severe and moderate immunodepression (CD4+<150 and $150<\mathrm{CD} 4+<350)$ respectively. Four years after they were linked to care, $9 \%$ and $28 \%$ still had severe and moderate immunodepression respectively. $14 \%, 34 \%$ and $40 \%$ of patients with $\mathrm{CD} 4+<150$ cells $/ \mathrm{ml}, \quad 150<\mathrm{CD} 4+<350$ cells $/ \mathrm{ml}$ and $350<\mathrm{CD} 4+<500$ cells $/ \mathrm{ml}$ respectively, reached a target of 500 cells $/ \mathrm{ml}$ or more after 4 years of treatment (Table1).
Immune recovery for viral suppressed patients $(\mathrm{VL}<1000)$ taking Efavirenz and Nevirapine for 4 years

CD4+ T-cell counts increased by $73 \%$ (90 - 338 cells $/ \mathrm{ml}), 49 \%$ (240 - 469 cells $/ \mathrm{ml})$ and $29 \%$ (407 - 552 cells $/ \mathrm{ml}$ ) for patients that started treatment with $\mathrm{CD} 4+<150$ cells $/ \mathrm{ml}$, $150<\mathrm{CD} 4+<350$ cells $/ \mathrm{ml}$ and $350<\mathrm{CD} 4+<500$ cells $/ \mathrm{ml}$, respectively. There was a significant difference amongst patients in different immune state during the four years of treatment (Table 2). There was a significant difference amongst patients either on $\mathrm{TDF}+3 \mathrm{TC}+\mathrm{EFV}$ and $\mathrm{TDF}+3 \mathrm{TC}+\mathrm{NVP}$ during the four years of treatment. The difference was not significant between the two protocols. CD4+ T-Cells count increase by $41 \%$ (265 - 446 cells $/ \mathrm{ml})$, $52 \%$ (217 - 457 cells $/ \mathrm{ml}), 50 \%$ (206 - 412 cells $/ \mathrm{ml})$ and 53\% (199 - 424 cells $/ \mathrm{ml})$ for patients with the age range $<30$ years, 30 to 40 years, 40 to 50 years and $>50$ years respectively (Table 2).

Likelihood association between age, gender, regimen and CD4+ T-cells count after four years of treatment for $n=499$ participants

Women were likely to reconstitute their CD4+ compared to male with $\mathrm{p}=0.006$. Participants aged less than 30 years old and those aged more than 50 years old were likely to have CD4+ less than $350 \mathrm{Cells} / \mathrm{ml}$, but that association was not statistically significant (Table 3).

Logistic regression between CD4+ T-cells, Gender, Sex, Viral load (VL), treatment and regimen

There was a significant association between CD4+ T-cells count and viral load $(\mathrm{p}=0.004, \mathrm{OR}=5.29,95 \% \mathrm{CI}=2.16-14.27)$ and Gender $(\mathrm{p}=0.005, \mathrm{OR}=0.51,95 \% \mathrm{CI}=0.32$ 0.82 ). The association with rupture of treatment, regimen, age, and regularity of treatment were not statistically significant (Table 4). 
Table 1: Sociodemographic and clinical characteristics for the 499 HIV infected individuals.

\begin{tabular}{|c|c|c|}
\hline Parameters & Modality & n $(\%)$ \\
\hline \multirow[t]{2}{*}{ Gender $(n=499)$} & Male & $160(32 \%)$ \\
\hline & Female & $339(68 \%)$ \\
\hline \multirow[t]{2}{*}{ Regimen } & $\mathrm{TDF}+3 \mathrm{TC}+\mathrm{EFV}$ & $400(80 \%)$ \\
\hline & $\mathrm{TDF}+3 \mathrm{TC}+\mathrm{NVP}$ & $99(20)$ \\
\hline \multirow[t]{4}{*}{ Immune state at initiation (cell/ml) } & $\mathrm{CD} 4<150$ & $167(33 \%)$ \\
\hline & $150<\mathrm{CD} 4<350$ & $201(40 \%)$ \\
\hline & $350<\mathrm{CD} 4<500$ & $77(15 \%)$ \\
\hline & $\mathrm{CD} 4>500$ & $54(11 \%)$ \\
\hline \multirow[t]{4}{*}{ After 4 years $($ cell $/ \mathrm{ml})$} & $\mathrm{CD} 4<150$ & $45(9 \%)$ \\
\hline & $150<\mathrm{CD} 4<350$ & $139(28 \%)$ \\
\hline & $350<\mathrm{CD} 4<500$ & $134(27 \%)$ \\
\hline & $\mathrm{CD} 4>500$ & $181(36 \%)$ \\
\hline \multirow[t]{2}{*}{ Virologic state (copies/ml) } & $\mathrm{VL}<40$ & $375(75 \%)$ \\
\hline & $40<\mathrm{VL}<1000$ & $124(25 \%)$ \\
\hline \multirow[t]{4}{*}{ Treatment interruption } & Never & $495(98 \%)$ \\
\hline & $<2$ weeks & $2(1 \%)$ \\
\hline & 2 to 4 weeks & $2(1 \%)$ \\
\hline & $>4$ weeks & $0(0 \%)$ \\
\hline \multirow[t]{3}{*}{ Reason for interruption } & Negligence & $1(0.3 \%)$ \\
\hline & Drug stock out & $2(1 \%)$ \\
\hline & Others & $1(0.3 \%)$ \\
\hline Age $($ median \pm SD $)$ & $40 \pm 5(22-68)$ & \\
\hline
\end{tabular}

Note: Efv: Efavirenz, NVP: Nevirapine, TDF: Tenofovir, 3TC: Lamivudine, VL: viral load, CD: clusters of differentiation, SD: standard deviation

Table 2: Immune recovery for viral suppressed patients taking Efavirenz and Nevirapine for 4 years.

\begin{tabular}{|c|c|c|c|c|c|c|c|}
\hline \multirow[t]{2}{*}{ Parameters } & S $\quad$ Modality & $\begin{array}{ll}\text { CD4 } & 1^{\text {st }} \\
\text { year } & \\
\end{array}$ & $\begin{array}{ll}\text { CD4 } & 2^{\text {nd }} \\
\text { year } & \\
\end{array}$ & $\begin{array}{ll}\text { CD4 } & 3^{\text {rd }} \\
\text { year } & \end{array}$ & $\begin{array}{ll}\text { CD4 } & 4^{\text {th }} \\
\text { year } & \end{array}$ & \multirow[t]{2}{*}{$\begin{array}{c}\text { increased } \\
\%\end{array}$} & \multirow[t]{2}{*}{ p value } \\
\hline & & \multicolumn{4}{|c|}{ Median (range) } & & \\
\hline \multirow{3}{*}{$\begin{array}{l}\text { Immune } \\
\text { state } \\
(\text { cell } / \mathrm{ml})\end{array}$} & CD4<150 & $90(6-149)$ & $\begin{array}{l}226(6- \\
845)\end{array}$ & $\begin{array}{l}310(3- \\
931)\end{array}$ & $\begin{array}{l}338(42- \\
1001)\end{array}$ & 73 & $p<0.001$ \\
\hline & $150<\mathrm{CD} 4<350$ & $\begin{array}{l}240(152- \\
350)\end{array}$ & $\begin{array}{l}360(36- \\
1160)\end{array}$ & $\begin{array}{l}433(35- \\
1133)\end{array}$ & $\begin{array}{l}469(150- \\
1480)\end{array}$ & 49 & $p<0.001$ \\
\hline & $350<\mathrm{CD} 4<500$ & $\begin{array}{l}407(350- \\
499)\end{array}$ & $\begin{array}{l}416(128- \\
979)\end{array}$ & $\begin{array}{l}540(52- \\
1282)\end{array}$ & $\begin{array}{l}\text { 552(203- } \\
1044)\end{array}$ & 29 & $p<0.001$ \\
\hline
\end{tabular}




\begin{tabular}{|c|c|c|c|c|c|c|c|}
\hline & CD4>500 & $\begin{array}{l}\text { 641(504- } \\
1527)\end{array}$ & $\begin{array}{l}504(70- \\
1862)\end{array}$ & $\begin{array}{l}592(80- \\
1921)\end{array}$ & $\begin{array}{l}\text { 606(210- } \\
1549)\end{array}$ & -5 & $\mathrm{p}=0.002$ \\
\hline \multirow[t]{2}{*}{ Protocol } & $\mathrm{TDF}+3 \mathrm{TC}+\mathrm{EFV}$ & $\begin{array}{l}224(14- \\
1124)\end{array}$ & $\begin{array}{l}348.5(6- \\
1862)\end{array}$ & $\begin{array}{l}413.5(52- \\
1921)\end{array}$ & $\begin{array}{l}431.0(88- \\
8114)\end{array}$ & 48 & $\mathrm{p}<0.001$ \\
\hline & $\mathrm{TDF}+3 \mathrm{TC}+\mathrm{NVP}$ & $\begin{array}{l}180(6- \\
1527)\end{array}$ & $\begin{array}{l}332(6- \\
1075)\end{array}$ & $\begin{array}{l}417.5(3- \\
1151)\end{array}$ & $\begin{array}{l}\text { 484(42- } \\
1064)\end{array}$ & 63 & $\mathrm{p}<0.001$ \\
\hline \multirow[t]{4}{*}{$\begin{array}{l}\text { Age } \\
\text { (years) }\end{array}$} & $<30$ & $\begin{array}{l}265(24- \\
1527)\end{array}$ & $\begin{array}{l}374(70- \\
1086)\end{array}$ & $\begin{array}{l}\text { 408(145- } \\
1921)\end{array}$ & $\begin{array}{l}446(146- \\
1004)\end{array}$ & 41 & $p=0.008$ \\
\hline & 30 to 40 & $\begin{array}{l}217(12- \\
1124)\end{array}$ & $\begin{array}{l}382.3(6- \\
1160)\end{array}$ & $\begin{array}{l}429.0(3- \\
1151)\end{array}$ & $\begin{array}{l}457.0(89- \\
1480)\end{array}$ & 52 & $\mathrm{p}<0.001$ \\
\hline & 40 to 50 & $\begin{array}{l}206.0(6- \\
1078)\end{array}$ & $\begin{array}{l}327.0(36- \\
1862)\end{array}$ & $\begin{array}{l}441.0(35- \\
1921)\end{array}$ & $\begin{array}{l}412(80- \\
8114)\end{array}$ & 50 & $\mathrm{p}<0.001$ \\
\hline & $>50$ & $\begin{array}{l}199.0(14- \\
809)\end{array}$ & $\begin{array}{l}331.0(6- \\
1043)\end{array}$ & $\begin{array}{l}364.0(90- \\
950)\end{array}$ & $\begin{array}{l}424.0(88- \\
1094)\end{array}$ & 53 & $\mathrm{p}<0.001$ \\
\hline \multirow[t]{2}{*}{ Gender } & Male & $\begin{array}{l}\text { 191.5(6- } \\
1527)\end{array}$ & $\begin{array}{l}311.5(6- \\
1036)\end{array}$ & $\begin{array}{l}348.0(3- \\
1921)\end{array}$ & $\begin{array}{l}381.5(80- \\
3441)\end{array}$ & 50 & $p<0.001$ \\
\hline & Female & $\begin{array}{l}234.0(12- \\
1099)\end{array}$ & $\begin{array}{l}357.0(26- \\
1862)\end{array}$ & $\begin{array}{l}442.5(35- \\
1282)\end{array}$ & $\begin{array}{l}491.5(42- \\
8114)\end{array}$ & 52 & $\mathrm{p}<0.001$ \\
\hline
\end{tabular}

Note: Efv: Efavirenz, NVP: Nevirapine, TDF: Tenofovir, 3TC: Lamivudine, CD4: clusters of differentiation 4.

Table 3: Likelihood association between age, gender, regimen and CD4 T-Cells count.

\begin{tabular}{|c|c|c|c|c|c|c|}
\hline $\begin{array}{l}\text { Explanatory } \\
\text { variables }\end{array}$ & & $\mathbf{N}$ & CD4 $<350$ & CD4>350 & OR $(95 \% \mathrm{CI})$ & p value \\
\hline \multirow[t]{2}{*}{ Gender } & Women & 240 & $65(27.1)$ & $175(72.9)$ & Reference & \\
\hline & Men & 112 & $47(42.0)$ & $65(58.0)$ & $0.51(0.32-0.82)$ & $p=0.006$ \\
\hline \multirow[t]{4}{*}{ Age (years) } & $<30$ & 45 & $15(33.3)$ & $30(66.7)$ & Reference & \\
\hline & 30 to 40 & 136 & $40(29.4)$ & 96(70.6) & $1.20(0.57-2.44)$ & $\mathrm{p}=0.620$ \\
\hline & 40 to 50 & 106 & $37(34.9)$ & $69(65.1)$ & $0.93(0.44-1.93)$ & $\mathrm{p}=0.852$ \\
\hline & $>50$ & 65 & $20(30.8)$ & $45(69.2)$ & $1.12(0.49-2.53)$ & $\mathrm{p}=0.777$ \\
\hline \multirow[t]{2}{*}{ Regimen } & $\mathrm{TDF}+3 \mathrm{TC}+\mathrm{EFV}$ & 279 & $90(33.5)$ & $179(66.5)$ & Reference & \\
\hline & $\mathrm{TDF}+3 \mathrm{TC}+\mathrm{NVP}$ & 83 & $22(26.5)$ & $61(73.5)$ & $1.39(0.81-2.45)$ & $\mathrm{p}=0.236$ \\
\hline
\end{tabular}

Note: Efv: Efavirenz, NVP: Nevirapine, TDF: Tenofovir, 3TC: Lamivudine, CD: clusters of differentiation.

Table 4: Univariable Logistic regression between CD4 T-cells and other variables.

\begin{tabular}{lllll}
\hline $\begin{array}{l}\text { Explanatory } \\
\text { variable }\end{array}$ & OR & $\mathbf{9 5 \%}$ CI & p-value & Model \\
\hline VL<1000 (copies/ml) & 5.29 & $(2.16-14.27)$ & $\mathbf{0 . 0 0 4}$ & CD4 $=-0.76+1.66$ VL \\
age (years) & 0.99 & $(0.97-1.02)$ & 0.743 & CD4 $=0.91-0.003 *$ Age \\
Gender & 0.51 & $(0.32-0.82)$ & $\mathbf{0 . 0 0 5}$ & CD4 $=0.99-0.66 *$ Sex \\
Regimen & 1.39 & $(0.81-2.45)$ & 0.236 & $\mathbf{C D 4}=0.6876+0.33 *$ Molecule \\
Regularity & 4.41 & $(0.85-32.14)$ & 0.089 & $\mathbf{C D 4}=-0.69+1.48 *$ Reg \\
Rupture oftreatment & 0.57 & $(0.15-2.36)$ & 0.416 & $\mathbf{C D 4}=0.77-0.55 *$ treatment Iinteruption \\
\hline
\end{tabular}




\section{DISCUSSION}

This was a retrospective cohort study with the aim to evaluate the kinetics of CD4+ T-cell recovery amongst viral suppressed patients on first-line ART for four years. It has been found that $33 \%$ and $40 \%$ of the patients had severe and moderate immunodepression at baseline respectively. $9 \%$ and $28 \%$ of those patients remain respectively on the same immunological state four years ago. This is highlighting the high rate of patients subject to immune disorders even though their viral load is less than 1000 copies/ml while starting treatment. Some authors (Lawn et al., 2006; Ahn et al., 2015; Pastor et al., 2018) found that HIV infection is follow by important immune phenomenon having a direct impact on T-cells subsets. Cytokine pro-inflammatory response cascade could be at the certain level responsible to the observed immune defect in some patients (Pastor et al., 2018). In many sub-Saharan settings, test and treat strategy has been put in place and patients are followed up using the viral load (Stafford et al., 2019). However, patients enrolled in ART with low CD4+ T-cells count have high risk of morbidity and mortality (Lawn et al., 2006; Danforth et al., 2017). Immunological nonresponse observed in this study might raise the concern about the immune follow up for patients on ART in resource limited settings.

It has also been realized that the CD4+ T-Cells count increased by $73 \%, 49 \%$ and $29 \%$ for patients that started treatment with CD $4+<150$ cells $/ \mathrm{ml}, 150<\mathrm{CD} 4+<350$ cells $/ \mathrm{ml}$ and $350<\mathrm{CD} 4+<500$ cells $/ \mathrm{ml}$ respectively. The significant increase in CD4+ T-cells observed join the HIV treatment objective and it is well known that initiation of antiretroviral therapy has improved significantly the reconstitution of CD4+ T-cells with a low risk of associated advert disease effect (Tran et al. 2017; OARAC 2019). Although the increase of CD4+ T-cells, $14 \%, 34 \%$ and $40 \%$ of patients with CD $4+<150$ cells $/ \mathrm{ml}, 150<\mathrm{CD} 4+<350$ cells $/ \mathrm{ml}$ and $350<\mathrm{CD} 4+<500$ cells $/ \mathrm{ml}$ respectively, reached a target of 500 cells $/ \mathrm{ml}$ or more after 4 years of treatment. The most the patients start treatment with low $\mathrm{CD} 4+$, the most it is difficult for them to reach the immune competence. Some studies show that patients put on ART with CD4+ T-cells less than 200 cells/ml may have a weak immune recovery one and five years after treatment (Lawn et al., 2006; Ahn et al., 2015; Merci et al., 2017). The reconstitution was significantly associated to the protocol, gender and age. Young and elder patients were likely to have CD4+ T-cells less than 350 cells $/ \mathrm{ml}$. Previous studies have shown that some factors such as age, specific drug regimen, and initial CD4+ T-cells count have a significant impact on immune recovery among virological suppressed patients on antiretroviral therapy (Merci et al., 2017; Stirrup et al., 2018).

Some limitations are recognized for this study. It was difficult to get a complete immune profile markers and some clinical and infectious factors like co-infections, clinical stage, etc because of poor documentation.

\section{Conclusion}

This study shows that many patients (about 35\%) infected by HIV were put on treatment while developing moderate immunosuppression. After four years of treatment, about $70 \%$ of patients were unable to reach the level of 500 cells $/ \mathrm{ml}$. CD4+ Tcells recovery is constituting a huge challenge in developing countries for the monitoring of HIV infected individuals and prevention of advert immune event like non-AIDS diseases.

\section{COMPETING INTERESTS}

All the authors of this paper declare no competing interests in this work.

\section{ACKNOWLEDGEMENTS}

The Yaoundé University Teaching Hospital and Essos Hospital Center.

\section{AUTHORS' CONTRIBUTIONS}

CHM, JMN and GMI: Development of research concept, data collection and analyzes, interpretation of results and participation in the initial draft of the manuscript. CMF, FAA, LMN, APNN, MCOA and GBJ: Development of research concept and drafting of manuscript. CRYD, MM: Contribution in the data 
collection. All authors read and approved the final version of the manuscript.

\section{REFERENCES}

Agosto LM, and Andrew JH. 2018. CD4+ T Cell Subsets and Pathways to HIV Latency. AIDS Research and Human Retroviruses., 34(9): 780-89. DOI: https://doi.org/10.1089/AID.2018.0105.

Ahn JY, David B, Matthew L, Nagalingeswaran K, Evy Y, Romanee C and Man P. 2015. Effects of CD4 Monitoring Frequency on Clinical Endpoints in Clinically Stable HIVInfected Patients with Viral Suppression. Journal of Acquired Immune Deficiency Syndromes., 69(3): e85-92. DOI: https://doi.org/10.1097/QAI.0000000000 000634.

Bonnet B, Laurent B, Charlotte C, Pascale M, Paul-Gydeon R, Brigitte A, and Amélie G. 2019. Short Communication: Extremely Severe CD4 Lymphopenia During HIV-1 Primary Infection. AIDS Research and Human Retroviruses., 35(10): 930-933. DOI: https://doi.org/10.1089/aid.2019.0065.

Cameroon_National-Integrated-HIVGuidelines. 2014. Accessed 10 July 2020. Retrieved from: https://www.childrenandaids.org/sites/de fault/files/2017-05/Cameroon_NationalIntegrated-HIV-Guidelines2014.pdf.

Danforth K, Reuben G, Danielle W, Sanjiv B, and Nancy P. 2017. Global Mortality and Morbidity of HIV/AIDS. In Major Infectious Diseases, edited by King KH, Bertozzi S, Barry RB, and Prabhat J, 3rd ed. Washington (DC): The International Bank for Reconstruction and Development / The World Bank. Retrieved from: http://www.ncbi.nlm.nih.gov/books/NB K525184/.

Darraj, Majid, Leigh A. Shafer, Shanna Chan, Ken Kasper, and Yoav Keynan. 2018. Rapid CD4 Decline Prior to Antiretroviral Therapy Predicts Subsequent Failure to Reconstitute despite HIV Viral Suppression. Journal of Infection and Public Health., 11(2): 265-69.

DOI: https://doi.org/10.1016/j.jiph.2017.08.00 1.

Dwyer-Lindgren L, Michael AC, Amber S, Krista S, Kate FW, Naomi RP, Benjamin KM, et al. 2019. Mapping HIV Prevalence in Sub-Saharan Africa between 2000 and 2017. Nature, 570(7760): $189-193 . \quad$ DOI: https://doi.org/10.1038/s41586-0191200-9.

Hsu DC, Irini S, and Jintanat A. 2013. Serious Non-AIDS Events: Immunopathogenesis and Interventional Strategies. AIDS Research and Therapy., 10(1): 29. DOI: https://doi.org/10.1186/1742-6405-1029.

Lawn SD, Landon M, Linda-Gail B, and Robin W. 2006. CD4 Cell Count Recovery among HIV-Infected Patients with Very Advanced Immunodeficiency Commencing Antiretroviral Treatment in Sub-Saharan Africa. BMC Infectious Diseases 6(1): $59 . \quad$ DOI: https://doi.org/10.1186/1471-2334-6-59.

Merci NM, Uwimana E, Nzitakera A, Michael $\mathrm{H}$, Ingabire $\mathrm{J}$, Tuyishime $\mathrm{A}$, Beneyo $\mathrm{J}$, Akimana C, and Augustin TP. 2017. CD4+ Cells Recovery in HIV Positive Patients with Severe Immunosuppression at HAART Initiation at Centre MedicoSocial Cor-Unum, Kigali. Pan African Medical Journal., 26. DOI: https://doi.org/10.11604/pamj.2017.26.1 4.10488.

OARAC. 2019. Guidelines for the use of antiretroviral agents in adults and adolescent with HIV. Retrieved from https://clinicalinfo.hiv.gov/sites/default/f iles/guidelines/documents/ AdultandAdolescentGL.pdf.

Okoye AA and Louis JP. 2013. CD4(+) T-Cell Depletion in HIV Infection: Mechanisms of Immunological Failure. Immunological Reviews., 254 (1): 54-64. DOI: https://doi.org/10.1111/imr.12066.

WHO. 2016. Consolidated Guidelines on the Use of Antiretroviral Drugs for Treating and Preventing HIV Infection: 
Recommendations for a Public Health Approach. World Health Organization. Retrieved from https://apps.who.int/iris/handle/10665/20 8825.

Pastor L, Victor U, Jorge C, Erica P, Laura FS, Chenjerai J, Inacio M, Denise N, and Julià B. 2018. Dynamics of CD4 and CD8 TCell Subsets and Inflammatory Biomarkers during Early and Chronic HIV Infection in Mozambican Adults. Frontiers in Immunology., 8(1):1925. DOI:

https://doi.org/10.3389/fimmu.2017.019 25.

Porichis F and Daniel EK. 2011. HIV-Specific CD4 T Cells and Immune Control of Viral Replication. Current Opinion in HIV and AIDS., 6(3): 174-180. DOI: https://doi.org/10.1097/COH.0b013e328 3454058.

Rb-Silva R, Claudia N, Cecilia A, Emilia A, João CG, Ivo F, Rémi C, Andrew JY, Ana H, and Margarida CN. 2019. Thymic Function as a Predictor of Immune Recovery in Chronically HIV-Infected Patients Initiating Antiretroviral Therapy. Frontiers in Immunology., 10: 25. DOI: https://doi.org/10.3389/fimmu.2019.000 25.

Stafford KA, Solomon FO, Julia L, Ramat I, Akipu E, Mercy N and Gambo GA. 2019. Evaluation of the Clinical Outcomes of the Test and Treat Strategy to Implement Treat All in Nigeria: Results from the Nigeria Multi-Center ART Study. PLoS ONE., $\quad \mathbf{1 4}(7)$. https://doi.org/10.1371/journal.pone.021 8555.

Stirrup OT, Copas AN. Phillips AN, Gill MJ, Geskus RB, Touloumi G, Young J, Bucher HC, Babiker AG. 2018. Predictors of CD4 Cell Recovery
Following Initiation of Antiretroviral Therapy among HIV-1 Positive Patients with Well-Estimated Dates of Seroconversion. HIV Medicine., 19(3): 184-194.

DOI: https://doi.org/10.1111/hiv.12567.

Tough RH, and Paul JM. 2019. Interaction of the Host and Viral Genome and Their Influence on HIV Disease. Frontiers in Genetics., $\quad 9(1)$ : $720 . \quad$ DOI: https://doi.org/10.3389/fgene.2018.0072 0 .

Tran M, Evan W, Thomas K, Sophie P, David B, Huiru D, Silvia G, Julio SM and Milloy MJ. 2017. Increases in CD4 Cell Count at Antiretroviral Therapy Initiation among HIV-Positive Illicit Drug Users during a Treatment-as-Prevention Initiative in Canada. Antiviral Therapy., 22(5): 403-411. DOI: https://doi.org/10.3851/IMP3145.

Vidya V K, Krithika PK, Srikanth PT, and Luke EH. 2017. Pathophysiology of CD4+ T-Cell Depletion in HIV-1 and HIV-2 Infections. Frontiers in Immunology., $\quad \mathbf{8}(5) . \quad$ DOI: https://doi.org/10.3389/fimmu.2017.005 80.

Wang H, Tim MW, Austin C, Grant N, Hmwe HK, Emmanuela G and Simon IH. 2016. Estimates of Global, Regional, and National Incidence, Prevalence, and Mortality of HIV, 1980-2015: The Global Burden of Disease Study 2015. The Lancet HIV, 3(8): e361-387. DOI: https://doi.org/10.1016/S23523018(16)30087-X.

Warren JA, Genevieve C and Nilu G. 2019. Harnessing CD8+ T Cells Under HIV Antiretroviral Therapy. Frontiers in Immunology., $\quad \mathbf{1 0}(2) . \quad$ DOI: https://doi.org/10.3389/fimmu.2019.002 91. 